\title{
БІОТЕХНОЛОГІЯ ВИРОЩУВАННЯ ТА ПЕРЕРОБКИ ЕЙХОРНІЇ
}

\author{
С. Петренко ${ }^{1}$, Н. Кірович ${ }^{1}$, В. Ясько ${ }^{1}$, С. Сідашова ${ }^{2}$, \\ Г. Шлапак ${ }^{3}$, Н. Поварова ${ }^{3}$, В. Найда ${ }^{1}$ \\ ${ }^{1}$ Одеський державний аграрний університет, \\ ${ }^{2}$ Аграрна дорадча служба Одеської області с. Петродолинське, Одеса \\ ${ }^{3}$ Одеська національна академія харчових технологій
}

Володарка незвичної для слуху назви ейхорнія (латаття, гіацинт) стає сільськогосподарською культурою в Україні. Перший практичний досвід отримання зеленої маси придбаний в експериментальному фермерському господарстві "У Самвела" в Одеській області. Тут розроблена інновачійна біотехнологія вирощування, а також техніка подальшого застосування на корм тваринам і птахам зеленої маси водяного гіацинта. Культуру вирощують i в теплииях, $і$ в відкритих водоймах.

У краӥнах відповідного клімату не так давно почали масово вирощувати гіаџинт для вживання його в їжу, як салат, $i$ з метою виготовлення органічного палива. Перспективність вирошування в умовах Одеської області ейхорнії $i$ застосуванні иієї культури в годівлі продуктивних тварин, як у вигляді добавки до раціону свіжих рослин, так і після силосування.

Розроблена експериментальна методика силосування зеленої маси ейхорнії, яка передбачає певні технологічні прочеси. Зразки експериментального силосу виглядали і пахли краще, ніж взяті для порівняння зразки силосу з кукурудзи. Проведений органолептичний аналіз показав хорошу якість продукту: приємний фруктово-хлібний запах, зеленуватий колір, відсутність ознак псування, ивілі, гнилі.

Ключові слова: ейхорнія, корм, тварини, рослини, органічні технологї, біотехнологія, силос.

Постановка проблеми. Ейхорнія - це плаваюча на поверхні води водна рослина, добре себе почуває в теплих спокійних водах, багатих органікою. На батьківщині водний гіацинт - це практично безперервно квітучий трав'янистий багаторічник. Ейхорнія має колосальну швидкість росту в водоймах і має величезні адаптаційні здібності [1]. Ї̈̈ унікальність полягає в можливості використання в якості корму для тварин та птиці після того, як рослина виконає свою основну функцію по очищенню сільськогосподрських стоків тваринницької або птахівничої ферми. Що стосується широкого застосування ейхорнії для ботанічного очищення стічних вод, у біологів існує на сьогодні дві протилежні думки. У той же час водяний гіацинт відрізняється користю для акваріумів і ставків. Завдяки своїм здібностям абсорбера рослина чудово очища воду, робить іiі прозорою і прибирає неприємні запахи. Вона здатна вбирати отруйні інсектициди, важкі метали, продукти життєдіяльності риб і інші токсичні речовини [2].

Глобальна зміна клімату в бік потепління визначила зниження продуктивності основних сільськогосподарських культур, яке при стресових температурах досягає 50-60\%, а в окремі роки і значно більше. Тривалі посухи є однією з найсерйозніших проблем сільського господарства: протягом 20-го сторіччя середня температура повітря в Україні зросла на $8^{0} \mathrm{C}$. Висновки міжнародних експертів свідчать про те, що в найближчі роки температура повітря в холодну пору року буде знижуватися, а в теплу - рости, річна сума опадів - зменшуватися. Відповідно це вплине на рентабельність (а в деяких регіонах і доцільність) вирощування певних традиційних сільгоспкультур, в тому числі кормових [3].

Сучасний розвиток різних напрямків біотехнології дозволяє розглянути альтернативні можливості збагачення кормових раціонів продуктивних тварин, особливо жуйних, культивуванням нетрадиційних рослин, наприклад, таких як Ейхорнія (Eichornia crassipes), що відрізняється дуже високою біопродуктивністю. Ця культура в умовах України може розмножуватися тільки вегетативним шляхом, що передбачає розробку певної біотехнології ії вирощування і підготовки до введення в раціони тварин, про що йдеться в літературі і ми вже згадували в наших попередніх публікаціях [4]. 
Крім того, вирощування ейхорнії допоможе вирішити ряд серйозних екологічних проблем регіону, де катастрофічно збільшується кількість різних водойм з непридатним для використання якістю вод в результаті яких не контролюються скидів відходів виробництва, в тому числі і стоків тваринницьких ферм. На сьогодні серед біологів існує дві протилежні думки щодо широкого використання ейхорнії для біологічного очищення.

Відповідно до одного з них - для збільшення ефективності очищення стоків (можливо тільки в літній період) доцільно використовувати Ейхорнію, якій відводиться роль фітомеліоратора $\mathrm{i}$ ресурсоперетворювача - продуцента кормової маси [5].

Натуралізація (самостійне існування) цієї тропічної рослини в кліматі України вважається неможливим у зв'язку з відсутністю морозостійкості. Протилежна точка зору не виключає можливості поширення ейхорнії в водоймах південних регіонів 3 подальшою можливістю деградації їх екосистем. Тому рішення про широкомасштабні проекти із застосуванням ейхорнії слід приймати після зваженого аналізу всіх сторін проблеми і більш глибокого вивчення біологічних особливостей цієї культури [6].

Потужна коренева система ейхорнії забезпечує високу ефективність поверхневоадсорбційного поглинання поживних речовин. На поверхні коренів формуються селективні мікробіоценози (бактерії, водорості, мікробесхребетні і інші представники водної флори і фауни).

Саме цей мікробіоценоз дозволяє рослині бути таким ефективним очищувачем шляхом біологічного перетворення токсичних з'єднань в нешкідливі речовини. Зарубіжні дослідники називають цю красиву водну рослину потужною біохімічною лабораторією, яка здатна переробляти складні токсичні продукти $[7,8]$.

Було доведено, що ейхорнія нейтралізує накопичені токсичні речовини, ії зелена маса, після очищення містить цінні поживні речовини і придатна на корм тваринам і птиці $[9,10]$.

Ці дані були підтверджені при проведенні наукових дослідів з визначення хімічного складу і поживності зеленої маси ейхорнії. вирощеної в умовах біопруда, що входить в очисні споруди птахофабрики. Отримані дані про високий вміст каротину, ряду мінеральних речовин в зелених рослинах ейхорнії, але одночасно вони свідчать про недостатнє вивчення біологічних властивостей цієї культури [11].

Мета роботи. Метою наших досліджень було впровадження нової технології по вирощуванню ейхорнії в умовах біобасейнів відстійників поруч 3 тваринницькими підприємствами та подальшою переробкою врожаю зеленої маси на корм у вигляді силосу. Ця біотехнологія передбачає використання ейхорнії як кормового ресурса цілорічного - як в свіжому вигляді, так і після силосування.

Матеріал і методи досліджень. У фермерському господарстві "У Самвела" розглядали варіант раціонального використання врожаю ейхорнії цілорічно при впровадженні біотехнології силосування зеленої маси в фазу найбільшого накопичення в рослинах протеїну та інших біологічно активних речовин. Для клімату південних областей України це останні місяці літа $\mathrm{i}$ початок осені (серпень-вересень). Хімічний склад рослинної маси ейхорнії може значно змінюватися в залежності від середовища вирощування і віку рослин.

У відкритому біопруду ФГ "У Самвела" протягом літа 2019 року був вирощен урожай на рівні 180 кг зеленої маси ейхорнії з $1 \mathrm{~m}^{2}$ водної поверхні, а утворений придонний мул був восени використаний для добрива полей з посадками озимої пшениці.

Результати власних досліджень. Розроблена нами експериментальна методика силосування зеленої маси ейхорнії передбачала наступні технологічні процеси:

$\checkmark$ збір зелених рослин, вирощених в закритому біобасейні (разом з кореневою системою),

$\checkmark$ механічне подрібнення (розміри подрібнених частин рослини в межах $4 \times 2 \times 1$ см),

$\checkmark$ обробка методом аерації поверхні подрібненої маси робочим розчином бактеріальної закваски (виробництво «Укрпролайф») в співвідношенні, рекомендованому виробником закваски,

$\checkmark$ трамбування шарів обробленої зеленої маси (товщина кожного шару не більше 5 см) в спеціально підготовленої тарі (пластикова упаковка на 10 кг і скляна ємність на 3 кг),

$\checkmark$ заповнення тари повністю, упаковка 3 максимальним віддаленням повітря і щільне закривання вгорі всієї тари, 

iн.),

$\checkmark$ маркування тари (дата закладки експериментального зразка силосу, кількість закваски,

$\checkmark$ зберігання готових зразків експериментального силосу в закритому вигляді в умовах приміщення лабораторії ФГ при кімнатній температурі,

$\checkmark$ відбір зразків для оцінки якості силосу через 21 день 3 подальшим повтором у міру необхідності.

Відповідно до технології приготування силосу з високобілкових культур, нами були відібрані зразки експериментального силосу після 21 дня від закладки для аналізу якості. Комісійно проведений органолептичний аналіз показав хорошу якість продукту: приємний фруктово-хлібний запах, зеленуватий колір, відсутність ознак псування, цвілі, гнилі. Відзначено більш висока, ніж бажано, вологість силосу, що пов'язано з високою вологістю закладається сировини. Зразки експериментального силосу виглядали і пахли краще, ніж взяті для порівняння зразки силосу з кукурудзи.

Результати хіміко-аналітичного лабораторного випробування підтвердили висновки про придатність експериментальних зразків силосу з ейхорнії для використання в годуванні тварин. В цілому за всіма показниками силос відповідав вимогам першого класу (табл. 1), але відзначено наявність підвищеної вологості, що вимагає удосконалення технології силосування 3 урахуванням біологічних особливостей рослин - гідробіонтів.

Таблиця 1.Дані лабораторних досліджень якості експериментальних зразків силосу із зеленої маси ейхорнії ( 3 корінням) *

\begin{tabular}{|c|c|c|}
\hline Показник & Силос ейхорнії (ФГ «У Самвела») & Норма до 1 класу \\
\hline Запах & Відповідає, приємний & приємний \\
\hline Колір & Зелений, відповідає & зелений \\
\hline Консистенція & $\begin{array}{l}\text { Волога, необхідна корекція } \\
\text { сировини для зниження вологості } \\
\text { силосної маси }\end{array}$ & відповідно \\
\hline Суха речовина, $\%$ & 8,0 & 25 \\
\hline $\begin{array}{lc}\text { Масова частка } & \text { масляної } \\
\text { кислоти,\%, не більше } & \end{array}$ & 0,1 & 0,3 \\
\hline $\begin{array}{l}\text { Масова частка оцтової кислоти,\%, } \\
\text { не більше }\end{array}$ & 1,4 & 3,5 \\
\hline $\mathrm{pH}$ & 3,4 & 3,9 \\
\hline Сирий протеїн,\% & 10,9 & 10 \\
\hline Зола,\% & 1,0 & - \\
\hline $\begin{array}{l}\text { Сира клітковина,\% } \\
\text { трохи більше }\end{array}$ & 19,1 & 29 \\
\hline Токсичність & Відсутне & Не допускається \\
\hline $\begin{array}{l}\text { Наявність цвілевих допускається } \\
\text { мікроскопічних грибів }\end{array}$ & відсутне & \\
\hline Масова частка жиру,\% & 4,1 & - \\
\hline висновок: & $\begin{array}{l}\text { Відповідає нормативам за всіма } \\
\text { показниками, крім вмісту сухої } \\
\text { речовини }\end{array}$ & - \\
\hline
\end{tabular}

* - Чернігівська регіональна лабораторія державної служби України з питань безпеки харчових продуктів та захисту прав споживачів

Нами було проведено виробничий демонстраційний експеримент 3 поїдання експериментального силосу жуйними тваринами, а саме - коровами і телятами, які утримувались в різних господарствах (досвідчена ферма клініки ветеринарного факультету ОДАУ і молочний комплекс агрофірми «Петродолинське»). Всі обстежені тварини знаходилися під контролем ветеринарної служби протягом досліду і потім протягом місяця не відзначено ознак негативного впливу на здоров'я корів і телят поїдання нового для них корму. 
Висновки. Таким чином, підсумовуючи результати наших досліджень можна зробити висновок про перспективність вирощування в умовах Одеської області ейхорнії і застосуванні цієї культури в годуванні продуктивних тварин, як у вигляді добавки до раціону свіжих рослин, так i після силосування. Для ефективного використання всіх можливостей цієї високобілковою культури слід більш глибоко вивчити іiї біологічні особливості як продуцента біомаси, а також перспективи ботанічного очищення токсичних відходів тваринницьких ферм.

\section{Список використаних джерел}

1. Информационный обзор способа очистки (доочистки) вод с применением эйхорнии (водного гиацинта) // [Электронный ресурс]. Режим доступа: http://www/essentuki.com.

2. Киреева В.В. Комплексная переработка вегетативной массы сельськохозяйственных растений/ В.В. Киреева // Росто-на Дону: РГАСХМ. 2004. 190с.

3. Коганов М.М. Комплексный поход в влажному фракционированию зелених растений с получением кормового и пищевого Белка, лекарств и биостимуляторов / М.М. Коганов // Mechanizacij u agrocompleksu. Zbornik zadova sa simposiuma. Obrenovac. 1990/ P. 193-200.

4. Сапарбекова А.А. Производство полноценных биокормов / А.А. Сапарбекова, А.Б. Утельбаева // [Электронный ресурс]. Режим дотупа:www.ecolife.ru/jornal/emed/ 1999-4-3-shtm.

5. Сидашова С.О. Експрес-біотестування кормів в умовах ферми з використанням культури інфузорії колоди / С.О. Сідашова// Эксклюзивные технологи. 2017.№ 1 (46). С. 58-60.

6. Технологии бизнеса с использованием водного гиацинта (эйхорнии)// [Электронный pecypc]. Режим дотупа:www.sapropex.ru/ p. 154 htm/.

7. Производство корма их эйхорнии после очистки бытовых стоков //[Электронный ресурс]. Режим доступа: // www.agrobook.ru//ochistka-stochnyh-vod.eyhorney.

8. Эйхорния отличная//[Электронный ресурс]. Режим доступа: http://ruwikipedia.org/wik.

9. Knight R.I. Wildlife habitat and public use benefits of treatment wetlands / R.I. Knight // Water Sci.Tech. 1997. Vol. 35, N. 5. P. 35-43.

10. Morris T.L. Water Hyacinth (Eicchornia crassipes (Mart.) Solms): its ability to invade aquatic ecosystems at Paynes Prairie Preserve: Dissertation / T.L. Morris. Florida: University of Florida, Gainesville, 1974.

11. Oki Y., Ito M., Ueki K. Studies on the growth and reproduction of water hyacinth, Eichhornia crassipes (Mart.) Solms. Effect of nitrogen sources on the growth and reproduction. Weed Research 23, 1978. 120-125.

\section{БИОТЕХНОЛОГИЯ ВЫРАЩИВАНИЯ И ПЕРЕРАБОТКИ ЭЙХОРНИИ}

Петренко С., Сидашова С., Кирович Н., Ясько В., Шлапак Г., Поварова Н., Найда В.

Обладательница необычного для слуха названия эйхорния (кувшинка, гиачинт) становится сельскохозяйственной культурой в Украине. Первый практический опыт получения зеленой массы приобретенный в экспериментальном фермерском хозяйстве "У Самвела" в Одесской области. Здесь разработана инноваџионная биотехнология выращивания, а также техника дальнейшего применения на корм животным и птище зеленой массы водяного гиацинта. Культуру выращивают и в тепличах, и в открытых водоемах.

В странах соответствующего климата не так давно начали массово выращчвать гиацинт для употребления его в пищу, как салат, и с целью изготовления органического топлива. Перспективность выращивания в условиях Одесской области эйхорнии и применении этой культуры в кормлении продуктивных животных, как в виде добавки в рачион свежих растений, так и после силосования.

Разработана экспериментальная методика силосования зеленой массы эйхорнии, которая предусматривает определенные технологические процессы. Образиы экспериментального силоса выглядели и пахли лучше, чем взятые для сравнения образиьь силоса из кукурузы. Проведенный органолептический анализ показал хорошее качество продукта: приятный фруктово-хлебный запах, зеленый ивет, отсутствие признаков порчи, плесени, гнили.

Ключевые слова: эйхорния, корм, животные, растения, органические технологии, биотехнология, силос. 


\section{BIOTECHNOLOGY OF EYCHORNY GROWING AND PROCESSING}

Petrenko S., Sidashova S., Kirovich N., Yasko V., Shlapak H., Povarova N., Naida V.

The owner of the name Eichhornia (water lilies, hyacinths), which is unusual for hearing, is becoming an agricultural crop in Ukraine. The first practical experience of obtaining green mass was acquired in the experimental farm "U Samvela" in Odessa region. Innovative biotechnology of cultivation, and also technique of the further application on a forage to animals and birds of green weight of a water hyacinth is developed here. The culture is grown in greenhouses and in open water.

In countries with the same climate, hyacinths have recently begun to be grown en masse for consumption as a salad and for the production of fossil fuels. Prospects for growing in the Odessa region eichhornia and the use of this culture in the feeding of productive animals, both as a supplement to the diet of fresh plants and after ensiling.

An experimental method of ensiling the green mass of eichhornia has been developed, which provides for certain technological processes. Samples of experimental silage looked and smelled better than those taken for comparison samples of corn silage. Conducted organoleptic analysis showed good product quality: a pleasant fruity-bread smell, greenish color, no signs of spoilage, mold, rot.

Key words: eichhornia, fodder, animals, plants, organic technologies, biotechnology, silage. 